\title{
The Immunoprotective Efficacy of Exopolysaccharides Produced from Different Strains of Pseudomonas syringae against Human Pathogenic Pseudomonas aeruginosa
}

\author{
Wagih El-Shouny", Mohammed El-Anwar Osman, Ragdah Talat* and Heba El- \\ Zahaby \\ Botany Department, Faculty of Science and "Microbiology Department, Faculty of \\ Medicine, Tanta University, Tanta, 31527, Egypt.
}

\begin{abstract}
$\mathbf{E}$ XOPOLYSACCHARIDES (EPS) produced from Pseudomonas syringae pv. tomato, $P$. syringae davson 973 and $P$. syringae pv. coriandricola 908 were studied. Mice immunized (i.p.) with bacterial EPS preparations from three strains (divided into 3 days) and in the fifth day, challenged (s.c.) with $1 \mathrm{ml}$ of human pathogen P. aeruginosa 3 to each mouse, all groups of mice showed an increase in total leukocyte counts as well as neutrophil and monocyte numbers if compared with saline control group. Studing the active immunization by purified bacterial EPS on the counts of $P$. aeruginosa in lungs, spleens and livers of challenged mice revealed the protection of organs against bacteremia. Thus, the immunoprotective characters of the three purified EPSs could be concluded and recommended for prophylactic applications.
\end{abstract}

Keywords: Exopolysaccharides, P. aeruginosa, Mice, Immunization, Bacteremia.

\section{Introduction}

Humans are frequently infected by opportunistic pathogens that take advantage of their compromised immunological status to cause persistent and chronic infections. The Gramnegative bacterium Pseudomonas aeruginosa is one of those recurrent human pathogens. $P$. aeruginosa remains one of the most important pathogens in nosocomial infections, and it is often associated with skin, urinary tract and respiratory tract infections (El-Shouny, 2000 and Lavoie et al., 2011). Respiratory tract infections are of major relevance in cystic fibrosis patients given that $P$. aeruginosa deeply affects their pulmonary function, causing life-threatening infections (Hauser et al., 2011). One of the better-known adaptive resistance mechanisms of $P$. aeruginosa to evade either the host immune response and drug therapy is its ability to form biofilms. The Pseudomonas aeruginosa biofilm is an extremely stable capsule-like structure constituted primarily of polysaccharides, proteins, and DNA, in which PsI exopolysaccharide seems to be a key player for biofilm matrix stability (Ma et al., 2009). Quorum sensing signals promote the formation of
P. aeruginosa biofilms, which minimizes the entry of antimicrobial compounds inside bacterial cells and hinders the recognition of pathogen-associated molecular patterns (PAMPs) by the host immune system (Alhede et al., 2014). .Consequently, current treatments against $P$. aeruginosa fail to resolve infections before tissue deterioration occurs. To address this concern, more efficient alternatives to abolish $P$. aeruginosa infections have produced promising but not definitive results. Accordingly, several candidate $P$. aeruginosa vaccines have been developed by targeting outer membrane proteins (Opr), lipopolysaccharides (LPS), polysaccharides (PS) as reported by Horn et al. (2010), Kamei et al. (2011), Campodonico et al. (2011) and Hilker et al. (2015). Pseudomonas aeruginosa exopolysaccharide (Psl) is a serotypeindependent, antibody-accessible antigen that is prevalent among both nonmucoid and mucoid clinical isolates. Interestingly, monoclonal antibody (mAbs) that bound to one particular Psl epitope mediated potent opsonophagocytic killing of $P$. aeruginosa in vitro, inhibited bacterial attachment to cultured lung epithelial cells and provided potent prophylactic protection

\#Corresponding author emails: elshounyw@yahoo.com,wageh.elshoni@science.tanta.edu.eg. 
in multiple animal models of $P$ aeruginosa infection. So that, Psl is a novel protective antigen and that antibodies targeting Psl might be an effective measure for prophylaxis against $P$. aeruginosa infections in high-risk patients (Hraiech et al., 2015; Emmanuelle et al., 2017 and Alessio et al., 2017). This paper concerns with the enhancement of the immune response in mice induced by exopolysaccharides produced by different strains of Pseudomonas syringae against human pathogenic Pseudomonas aeruginosa.

\section{Materials and Methods}

Three strains of Gram-ve bacteria of Pseudomonas syringae (P. syringae pv. tomato, P. syringae pv. coriandericola 908, P. syringae davson 973 were studied for their alginate (EPS) protective efficacy against human pathogenic Pseudomonas aeruginosa.

\section{Isolation of exopolysaccharides}

Preparation of inoculum

For inoculum preparation, two successive pre-cultures were grown. The growth was measured turbidemetrically at $660 \mathrm{~nm}$ in order to standardize the quantity of the bacterial cells used for inoculation throughout the experiments. The first pre-culture was prepared by suspending aloop of bacteria in about $30 \mathrm{ml}$ of $\mathrm{KW}$ - medium (Keen \& Williams, 1971).

\section{Production of exopolysaccharides}

$250 \mathrm{ml}$ Eelenmeyer flasks were filled with $100 \mathrm{ml}$ of autoclaved medium and inoculated by $2 \%$ portion of the pre-culture of the experimental bacterium. The flasks were incubated at $37^{\circ} \mathrm{C}$ for 1 day in rotary shaker $(120 \mathrm{rpm})$. At the end of the incubation period, the bacteria were pelleted by centrifugation and re-centrifugation at $6000 \mathrm{rpm}$. The clear supernatant was used for further investigations since it contained the crude Bacterial EPS.

\section{Partial purification of exopolysaccharides}

The culture supernatant was treated by the addition of trichloroacetic acid (TCA) 5\% for removing protein according to Khalil (2002) and stored at freezer overnight. The supernatant was mixed with three volumes of $95 \%$ of ethanol, stirred vigorously overnight at $4^{\circ} \mathrm{C}$. The resultant precipitate was recovered by centrifugation at $3000 \mathrm{rpm}$ for $20 \mathrm{~min}$ ( $\mathrm{Wu}$ et al., 2008). Exopolysaccharides were estimated by phenol sulphuric assay (Dubois et al., 1956).

\section{Blood counts}

\section{Total white blood cell counts}

It was done according to Kruse et al. (1973) Firstly, red blood cells were removed by lyses in diluted acid to prevent the erroneous counting of red blood cells as small lymphocytes. Total white blood cell counts were determined by addition of $0.01 \%$ gentian violet in $3 \%$ acetic acid (Turk's solution) to facilitates counting since it stain the white blood cells.

\section{Procedure}

The appropriate dilutions of cell suspension prior to counting were made, the optimal concentration of cells was (50-100 cells per large square) after dilution in the counting solution, Pasteur pipette with finger control were used to lead the cell suspension flow under the cover slip until the grid area is just full, then all of the cells contained in each of the four large squares were counted, finally, the average number of the cells per large square must be determined by the following equation :

$$
\text { Cells } / \mathrm{ml}=\frac{\mathrm{N} \mathrm{X} 4000 \times 10}{16 \times 16}
$$

These were the number of cells per $4000 \mathrm{ml}$

$\mathrm{N}$ :- Total number of leucocytes counted in the 16 large square

The leucocytes count in all large squares $=16$

Number of dilution $=10$

Differential white blood cell counts

A blood film was treated by using Leishman stain, and the number of each type of leukocytes per field was recorded.

\section{Mice immunization}

Adult male mice, 6 to 8 weeks of age (weigh, 15 to $25 \mathrm{~g}$ ) were housed on the basis of study requirements. Mice were divided into 12 groups (6 animals per cage), out of them, three groups were taken as control groups. Three of the EPS obtained from the three P.syringae pathovars were subjected to test on mice.

\section{Mice lethal challenge}

The bacterial challenge dose of Pseudomonas aeurginosa which caused $>90 \%$ mortality within 2 days was determined to be the lethal dose. The bacterial challenge for the subsequent experiments was prepared as follows; P. aeurginosa was grown overnight (18-24h) on nutrient agar, the bacterial cells were collected and suspended in sterile 
phosphate- buffered solution (PBS). Bacterial cells were suspended to an optical density of 0.3 at $660 \mathrm{~nm}$., corresponding to $10^{8} \mathrm{CFU} / \mathrm{ml}$ as lethal dose, immediately before injection. Mice were challenged by administering intraperitoneal (i.p.) one $\mathrm{ml}$ of bacterial suspension. Non-immunized control mice were challenged with one $\mathrm{ml}$ of PBS (Fattom et al., 1996).

\section{Active immunization}

Mice were immunized subcutaneouly (s.c) in first, second and third days with $1 \mathrm{ml}$ of $P$. syringae EPS (divide into 3 doses). Animals were challenged intraperitoneal (i.p.) in fifth day with doses of $P$. aeurginosa $10^{7}$ and $10^{8} \mathrm{CFU} / \mathrm{ml}$ ). A serum sample was obtained from each mouse after 5 days of the last immunization and the mice of control group injected s.c with PBS were also bled concurrently and challenged (Fattom et al., 1996), blood samples were also collected from mice after bleeding for blood count (total and differential blood counts).

Mice were randomly selected and removed from cages at designated time points after challenge, selected mice were weighted, bled and evaluated for livers, spleens and lunges. Organs were excited, weighted, washed, with $70 \%$ ethyl alcohol to eliminate surface-attached organisms, then washed with sterile PBS, and homogenized in $1 \mathrm{ml}$ PBS. $0.1 \mathrm{ml}$ of this suspensions were cultured on King'B agar plates and bacteria were counted after overnight incubation and expressed as CFU per organ (Fattom et al., 1996).

\section{Results}

\section{Mice lethal challenge}

In Table 1, groups of non-immunized mice were injected intraperitoneally (i.p.) with different doses of virulent human pathogen $P$. aeruginosa ranged from $10^{5}$ to $10^{10} \mathrm{CFU} /$ mouse. It recorded that the bacterial challenge caused more than $75 \%$ mice mortality within two days of injection was $10^{8} \mathrm{CFU} /$ mouse and sub-lethal dose was $10^{7} \mathrm{CFU} /$ mouse. These doses were used for challenge in subsequent experiments.

TABLE 1. Effect of challenge doses of $P$. aeruginosa on mortality of non-immunized mice.

\begin{tabular}{lccccccc}
\hline $\begin{array}{l}\text { Bacterial } \\
\text { challenge i.p. } \\
\text { CFU/mouse }\end{array}$ & $\mathbf{1}$ & $\mathbf{2}$ & $\mathbf{3}$ & $\mathbf{4}$ & $\mathbf{5}$ & $\mathbf{6}$ & $\mathbf{7}$ \\
\hline $10^{5}$ & $0 / 4$ & $0 / 4$ & $0 / 4$ & $0 / 4$ & $0 / 4$ & $0 / 4$ & $0 / 4$ \\
$10^{6}$ & $2 / 4$ & $3 / 4$ & $4 / 4$ & $4 / 4$ & $4 / 4$ & $4 / 4$ & $4 / 4$ \\
$10^{7}$ & $3 / 4$ & $3 / 4$ & $2 / 4$ & $2 / 4$ & $4 / 4$ & $4 / 4$ & $4 / 4$ \\
$10^{8}$ & $4 / 4$ & $4 / 4$ & $4 / 4$ & $4 / 4$ & $4 / 4$ & $4 / 4$ & $4 / 4$ \\
$10^{9}$ & $4 / 4$ & $4 / 4$ & $4 / 4$ & $4 / 4$ & $4 / 4$ & $4 / 4$ & $4 / 4$ \\
$10^{10}$ & $4 / 4$ & $4 / 4$ & $4 / 4$ & $4 / 4$ & $4 / 4$ & $4 / 4$ & $4 / 4$ \\
\hline
\end{tabular}

-Numerator indicates the cumulative number of mice that dead and denominator indicates the number of mice used.

\section{Effect of bacterial challenge on leukocyte count}

Leukocyte counts of mice blood which infected only with $P$. aeruginosa, mice which immunized by bacterial EPS preparations and mice which immunized with bacterial EPS preparations and infected with $P$. aeruginosa 3 were presented in Table 2. The results revealed that all groups of mice recorded an increase in total leukocyte counts as well as neutrophil and monocyte numbers if compared with saline control group.

\section{Bacteremia}

Data present in Table 3 show the effect of (ip) active immunization by purified bacterial EPS on the counts of $P$. aeruginosa in lungs, spleens and livers of challenged mice. The data revealed the protection of organs against bacteremia except group 7 and group 8 which recorded bacterial cells in their lungs, spleen and liver. Group 7 immunized with $1 \mathrm{ml}$ P. syringae pv. tomato EPS and challenged with $1 \mathrm{ml}$ of lethal dose $\left(10^{8} \mathrm{CFU} /\right.$ mouse) recorded in lung $6 \times 10^{3} \mathrm{CFU}$, in spleen $11 \times 10^{2} \mathrm{CFU}$ and in liver ( two lobes ) was 34 $\mathrm{x} 10^{2} \mathrm{CFU}$. Group 8 immunized also with $1 \mathrm{ml} P$. syringae pv. tomato EPS and challenged with $1 \mathrm{ml}$ of sub-lethal dose $\left(10^{7} \mathrm{CFU} /\right.$ mouse $)$ recorded in lung $5 \times 10^{3} \mathrm{CFU}$, in spleen was $9 \times 10^{2} \mathrm{CFU}$ and in liver ( two lobes ) was $32 \times 10^{2} \mathrm{CFU}$. If compared with control groups group 2 and group 3 which recorded bacterial counts more than group 7 and group 8 . 
TABLE 2. Leukocytic count of mice blood that infected with $P$. aeruginosa after immunization by bacterial EPS preparation.

\begin{tabular}{|c|c|c|c|c|c|c|c|}
\hline \multirow[b]{2}{*}{$\begin{array}{l}\text { Group } \\
\text { No. }\end{array}$} & \multirow[b]{2}{*}{ Immunizing EPS } & \multicolumn{5}{|c|}{ Differential leukocyte count \% } & \multirow[b]{2}{*}{$\mathbf{A S}$} \\
\hline & & 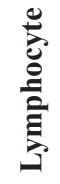 & 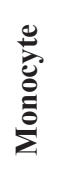 & 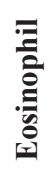 & 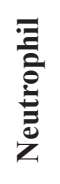 & 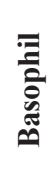 & \\
\hline 1 & $\begin{array}{l}\text { Control } \\
\text { (saline ) }\end{array}$ & 37 & 5 & 1 & 50 & 1 & 4175 \\
\hline 2 & $\begin{array}{l}\text { Control with } \\
\text { L.D }\end{array}$ & 14 & 18 & 2 & 65 & 1 & 5000 \\
\hline 3 & Control with S.L.D & 16 & 19 & 3 & 61 & 1 & 5100 \\
\hline 4 & $\begin{array}{l}\text { EPS from } \\
P . \text { syringae } \\
\text { pv. tomato }\end{array}$ & 14 & 17 & 2 & 66 & 1 & 5254 \\
\hline 5 & $\begin{array}{l}\text { EPS from } \\
\text { P. syringae } \\
\text { davson } 973\end{array}$ & 18 & 22 & 2 & 57 & 1 & 5451 \\
\hline 6 & $\begin{array}{l}\text { EPS from } \\
\text { P. syringae } \\
\text { pv.coriandericola } \\
908\end{array}$ & 20 & 18 & 1 & 60 & 1 & 5336 \\
\hline 7 & $\begin{array}{l}\text { EPS from } \\
\text { P. syringae } \\
\text { pv. tomato } \\
\text { with L.D }\end{array}$ & 12 & 21 & 1 & 65 & 1 & 5210 \\
\hline 8 & $\begin{array}{l}\text { EPS from } \\
\text { P. syringae } \\
\text { pv. tomato } \\
\text { with S.L.D }\end{array}$ & 13 & 20 & 2 & 65 & 1 & 5560 \\
\hline 9 & $\begin{array}{l}\text { EPS from } \\
\text { P. syringae } \\
\text { davson } 973 \\
\text { with L.D }\end{array}$ & 19 & 20 & 2 & 58 & 1 & 6900 \\
\hline 10 & $\begin{array}{l}\text { EPS from } \\
\text { P. syringae } \\
\text { davson } 973 \\
\text { with S.L.D }\end{array}$ & 16 & 16 & 2 & 65 & 1 & 7200 \\
\hline 11 & $\begin{array}{l}\text { EPS from } \\
\text { P. syringae } \\
\text { pv.coriandericola } 908 \\
\text { with L.D }\end{array}$ & 20 & 18 & 1 & 60 & 1 & 5750 \\
\hline 12 & $\begin{array}{l}\text { EPS from } \\
\text { P. syringae } \\
\text { pv.coriandericola } \\
908 \\
\text { with S.L.D }\end{array}$ & 20 & 20 & 4 & 55 & 1 & 5960 \\
\hline
\end{tabular}


TABLE 3. Effect of active immunization (ip) by purified bacterial EPS on the counts of $P$. aeruginosa in lungs, spleens and livers of challenged mice.

\begin{tabular}{|c|c|c|c|c|c|}
\hline \multirow{2}{*}{ Group No. } & \multirow{2}{*}{$\begin{array}{l}\text { Immunizing } \\
\text { EPS }\end{array}$} & \multirow{2}{*}{$\begin{array}{l}\mathrm{CFU} / \mathrm{ml} \\
1 \mathrm{ml} \text { of } \\
\text { challenge } \\
\text { bacteria }\end{array}$} & \multicolumn{3}{|c|}{ CFU / organ } \\
\hline & & & Lung & Spleen & Liver \\
\hline 1 & Control with saline & Saline & 0 & 0 & 0 \\
\hline 2 & Control with L.D & $10^{8}$ & $12 \times 10^{3}$ & $19 \times 10^{2}$ & $52 \times 10^{2}$ \\
\hline 3 & Control with S.L.D & $10^{7}$ & $9 \times 10^{3}$ & $16 \times 10^{2}$ & $39 \times 10^{2}$ \\
\hline 4 & $\begin{array}{l}\text { EPS from } P \text {. syringae } \\
\text { pv. tomato }\end{array}$ & ---- & 0 & 0 & 0 \\
\hline 5 & $\begin{array}{l}\text { EPS from } \\
\text { P. syringae } \\
\text { davson } 973\end{array}$ & ---- & 0 & 0 & 0 \\
\hline 6 & $\begin{array}{l}\text { EPS from } \\
\text { P. syringae } \\
\text { pv. coriandericola } \\
908\end{array}$ & ---- & 0 & 0 & 0 \\
\hline 7 & $\begin{array}{l}\text { EPS from } \\
\text { P. syringae } \\
\text { pv. tomato }\end{array}$ & $10^{8}$ & $6 \times 10^{3}$ & $11 \times 10^{2}$ & $34 \times 10^{2}$ \\
\hline 8 & $\begin{array}{l}\text { EPS from } \\
\text { P. syringae } \\
\text { pv. tomato }\end{array}$ & $10^{7}$ & $5 \times 10^{3}$ & $9 \times 10^{2}$ & $32 \times 10^{2}$ \\
\hline 9 & $\begin{array}{l}\text { EPS from } \\
\text { P. syringae } \\
\text { davson } 973\end{array}$ & $10^{8}$ & 0 & 0 & 0 \\
\hline 10 & $\begin{array}{l}\text { EPS from } \\
\text { P. syringae } \\
\text { davson } 973\end{array}$ & $10^{7}$ & 0 & 0 & 0 \\
\hline 11 & $\begin{array}{l}\text { EPS from } \\
\text { P. syringae } \\
\text { pv. coriandericola } \\
908\end{array}$ & $10^{8}$ & 0 & 0 & 0 \\
\hline 12 & $\begin{array}{l}\text { EPS from } \\
\text { P. syringae } \\
\text { pv. coriandericola } \\
908\end{array}$ & $10^{7}$ & 0 & 0 & 0 \\
\hline
\end{tabular}




\section{Discussion}

In Table 1, mice infection was accomplished by intraperitonial injection of the determined lethal dose of P. aeurginosa $10^{8} \mathrm{CFU} /$ mouse). At these dose more than $85 \%$ of non-immunized mice were died within two days of injection and also recorded decreasing of mice weight. These results indicated the presence of bacterial infection which causes death. Similar results were obtained by Fattom et al. (1996) found that a dose of $2 \times 10^{5} \mathrm{CFU}$ of S. aureus type $5 \mathrm{CP}$ per mouse administrated intraperitoneally (i.p.) with $5 \%$ hog mucin was found to cause 80 to $100 \%$ mortality in BALB/c mice within 2-5 days. While mice actively immunized with the monovalent type 5 CP-P. aeruginosa exoprotein. showed a survival rate of $73 \%$ compared with $13 \%$ in phosphatebuffered saline-immunized animals. Similar results were found by El-Shouny (2000) who reported that the mortality rate reached $>75 \%$ within 2 days in mice after (i.p.) injection with $10^{9} \mathrm{CFU} /$ mouse with $P$. aeruginosa. Also, Allam \& Elslik (2011) found that the use of lipopolysaccharide (LPS), exopolysaccharide (EPS) and mutant strain as subunit vaccines against intraperitoneal $(\mathrm{I} / \mathrm{P})$, challenge of Serratia marcescens W225 in mouse model referring to $E$. coli as standard, that elicit the secretions of IgM, which have protection role against lethal doses challenge, or their toxicity in mice through the follow up of liver enzymes, urea and weight. The results indicated that capsular or EPS and mutant strain ( $S$. marcescens W1765) antigens (vaccines) confer the highest protective immunization.

As shown in Table 2, the total white blood cells and differential count included neutrophils and monocytes were increased due to the bacterial challenge and lymphocytes were decreased due to the bacterial infection. In accordance with their results, Santos et al. (2008) reported that the decrease in lymphocyte counts was observed in parasitized animals with Gram-negative bacteria: Citrobacter divergens, Burkholderia cepacia, Stenotrophomonas maltophilia, Proteus vulgaris, Enterobacter sakazakii, Enterobacter ammnigenus, Pseudomonas aeruginosa, Pantoea sp. and Providencia rettgeri.

The obtained results from Table 3 revealed reduction of bacteremia as response of active immunization with $1 \mathrm{ml}$ of intraperitoneal (i.p) injection of purified EPS on three successive doses before bacterial challenge with $1 \mathrm{ml}$ P. aeruginosa (s.c). Group of mice immunized with EPS from P. syringae pv. tomato was dead when challenged with lethal dose $\left(10^{8} \mathrm{CFU} / \mathrm{ml}\right)$ but when challenged with sub-lethal dose $\left(10^{7} \mathrm{CFU} / \mathrm{ml}\right)$, the bacterial cells recorded in their lungs, spleens and livers were $5 \times 10^{3}, 9 \times 10^{2}$ and $32 \times 10^{2}$ CFU/organ, respectively, when compared with control groups which recorded higher bacterial counts. However, other groups of mice were immunized with EPS from $P$. syringae davson 973 and $P$. syringae pv. coriandricola 908 had no bacterial cells recorded in their lungs, spleens and livers, after bacterial challenge with lethal dose and sub-lethal dose, respectively, These data suggested that the dose of Pseudomonas syringae pv. tomato EPS did not exhibit immunization but the doses" of $P$. syringae davson 973 and P. syringae pv. coriandricola 908 "EPS in successive doses enhanced the immune response to overcome the bacterial challenge and preventing seeding of organs with bacteria. This was in agreement with Hatcher et al. (2015) who found that the immunogenicity of the polyvalent O-polysaccharide-toxin A conjugate vaccine reflected lower frequency of $P$. aeruginosa in sputum/throat cultures and preservation of lung function. Also, Gamboa et al. (2009) found that when animals (red deer) received vaccine (alginate composite microspheres containing a nonimmunogenic, eggshell-precursor protein of the parasite Fasciola hepatica) exhibited significant reduction in bacterial counts in their spleens. El-Shouny (2000) proved the immunoprotective efficacy of Pseudomonas syringae pv. coriandricola exopolysac chride against Pseudomonas aeurginosa infection in mice. Finally, Laroussarie et al. (2015) suggested that Pseudomonas aeruginosa exopolysaccharide (Ps l) is a serotype-independent, antibody-accessible antigen that is prevalent among both nonmucoid and mucoid clinical isolates. Interestingly, monoclonal antibody (mAbs) that bound to one particular Ps 1 epitope mediated potent opsonophagocytic killing of $P$. aeruginosa in vitro, inhibited bacterial attachment to cultured lung epithelial cells and provided potent prophylactic protection in multiple animal models of $P$. aeruginosa infection. So that, Ps 1 is a novel protective antigen and that antibodies targeting Ps 1 might be an effective measure for prophylaxis against $P$. aeruginosa infections in high-risk patients (Laroussarie et al. (2015); Lei et al. ( 2016) and Van et al. ( 2017).

It could be concluded that the three tested EPSs were proven to be immunoprotective and prophylactic agents against $P$. aeruginosa infection in mice. 


\section{Reffrences}

Alessio, C., Marco, I., Milena, P., Rosanna, C., Marco, S. and Antonio, Evidente (2017) An ELISA method to identify phytotoxic Pseudomonas syringae pv. actinidiae exopolysaccharides: A tool for rapid immunochemical detection of kiwifruit bacterial canker Phytochemistry Letters, 19, 136-140

Alhede M., Bjarnsholt, T., Givskov, M. and Alhede, M. (2014) Pseudomonas aeruginosa biofilms: mechanisms of immune evasion Advances in Applied Microbiology, 86,1-40.

Allam, N.G. and Elslik, S.E. (2011) Evaluation of lipopolysaccharide, exopolysaccharide and mutant strain as subunit vaccines against Serratia marcescens W225. African Journal of Microbiology Research, 12, 1389-1397.

Campodonico, V.L., Llosa, N.J., Bentancor, L.V., Maira-Litran, T. and Pier, G.B. (2011) Efficacy of a conjugate vaccine containing polymannuronic acid and flagellin against experimental Pseudomonas aeruginosa lung infection in mice. Journal of Infectious Diseases and Immunity, 79, 3455-64.

Dubois, M., Gilles, K.A., Hamilton, J.K., Rebers, P.A. and Smith (1956) Colorimetric method for determination of sugars and related substances. Anal.Chem. 28, 350- 356.

El-Shouny, W.A. (2000) Purification and immunoprotective efficacy of Pseudomonas syringae pv. coriandricola exopolysacchride against Pseudomonas aeurginosa infection in mice. $J$. of Pharmaceutical Sciences, 25, 149-165.

Emmanuelle, Z., Stuart, K. and Andrew, C.B. (2017) Immune transcriptome reveals the mincle $\mathrm{C}$-type lectin receptor acts as a partial replacement for TLR4 in lipopolysaccharide-mediated inflammatory response in barramundi (Lates calcarifer). Molecular Immunology, 83, 33-45

Fattom, A., Sarwar, J., Ortiz, A. and Naso, R. (1996) A Staphylococcus aureus capsular polysaccharide (CP) vaccine and $\mathrm{CP}$ - specific antibodies protect mice against bacterial challenge. Infection and Immunity, 64, 1659-1665.

Gamboa, A.M., Ficht, T.A., Davis, D.S., Elzer, P.H., Gonzalez, A.W. and Rice-Ficht, A.C. (2009) Enhanced immune response of red deer to live RB51 vaccine strain using composite microspheres. Journal of Wildlife Diseases, 45,165-173.

Hatcher, C.L., Muruato, L.A. and Torres, A.G. (2015) Recent Advances in Burkholderia mallei and B. pseudomallei Research. Current Tropical Medicine Reports Journal, 2, 62-69.

Hauser A.R., Jain, M., Bar-Meir, M. and McColley, S.A. (2011). Clinical significance of microbial infection and adaptation in cystic fibrosis. Clinical Microbiology Reviews, 24, 29-70.

Hilker, R., Munder, A., Klockgether, J., Losada, P.M., Chouvarine, P. and Cramer, N. (2015) Interclonal gradient of virulence in the Pseudomonas aeruginosa pangenome from disease and environment. Environmental Microbiology, 17, 29-46.

Horn, M.P., Zuercher, A.W., Imboden, M.A., Rudolf, M.P., Lazar, H. and Wu, H. (2010) Preclinical in vitro and in vivo characterization of the fully human monoclonal IgM antibody KBPA101 specific for Pseudomonas aeruginosa serotype IATS-O11. Antimicrob Agents Chemother, 54, 2338-2344.

Hraiech, S., Bregeon, F. and Rolain, J.M. (2015) Bacteriophage-based therapy in cystic fibrosisassociated Pseudomonas aeruginosa infections: rationale and current status. Drug Design and Development, 9, 3653-3663.

Kamei, A., Coutinho-Sledge, Y.S., Goldberg, J.B., Priebe, G.P. and Pier, G.B. (2011) Mucosal vaccination with a multivalent, live-attenuated vaccine induces multifactorial immunity against Pseudomonas aeruginosa acute lung infection. Journal of Infectious Diseases and Immunity, 79,1289-99.

Keen, N.T. and Williams, B.H. (1971) Chemical and biological properties of alipomucopolysaccharide from Pseudomonas lachrymans. Physiological and Molecular Plant Pathology, 1, 247-264.

Khalil, M.A. (2002) Studies on the production of polysaccharides by Azotobacters. M.D. Thesis, Tanta University, Faculty of Science, Departement of Botany, Egypt.

Kruse, M., Korting, W. and Rhoads, J. (1973) Effects of temperature on hematological and biochemical parameters of great sturgeon. Compar.Surgical Pathology Clinics, 4, 367-371.

Laroussarie, A., Barycza, B., Andriamboavonjy, H., Tamigney, K.M., Blériot, Y. and Gauthier, C. (2015)Synthesis of the tetrasaccharide repeating unit of the beta-Kdo-containing exopolysaccharide from Burkholderia pseudomallei and B. cepacia Complex. The Journal of Organic Chemistry, 80,10386-10396.

Lavoie, E.G., Wangdi, T. and Kazmierczak, B.I. (2011) Innate immune responses to Pseudomonas aeruginosa infection. Microbes and Infection, 13, 1133-1145.

Lei, Z., Fan, Z., Li, J.Y., Yang, G.E., Qing, F.W., and Epsa, H. (2016) An exopolysaccharide from Aphanothece halophytica GR02, improves both cellular and humoral immunity as a novel polysaccharide adjuvant. Chinese Journal of Natural Medicines, 14, 541-548.

Ma, L., Conover, M., Lu, H., Parsek, M.R., Bayles, 
K. and Wozniak, D.J. (2009) Assembly and development of the Pseudomonas aeruginosa biofilm matrix. PLoS Pathog, 5(3), 354.

Santos, K.R., Takahira, R.K., RallL, M., Calderon C, Sequeira J.L. and Silva, R.J. (2008) Pulmonary, microbiological and hematological changes in Crotalus durissus terrificus (Serpentes, Viperidae) parasitized by nematodes of the genus Rhabdias (Nematoda, Rhabdiasidae) .Journal Arquivo Brasileiro De Medicina Veterinriae Zootecnia, 60, 3-7.
Van, T.B., Charron, M., Reading, D.J., Reckseidler, S.L. and Lewenza, S. (2017) Exopolysacchariderepressing small molecules with antibiofilm and antivirulence activity against Pseudomonas aeruginosa. Antimicrob Agents Chemother, 16.

Wu, Y.C., Liang, Z.C., Lu, C.P. and Wu, S.H. (2008) Effect of carbon and nitrogen sources on the production and carbohydrate composition of exopolysaccharide by submerged culture of Pleurotus citrinopileatus. Food and Dr Analysis, 16, 61-67.

وجيه عبد الفتاح الثوني، محمد انور عثمان، رغده طلعت* و هبه الذهبي

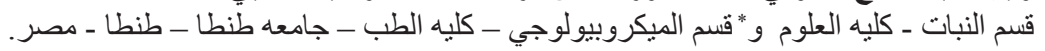

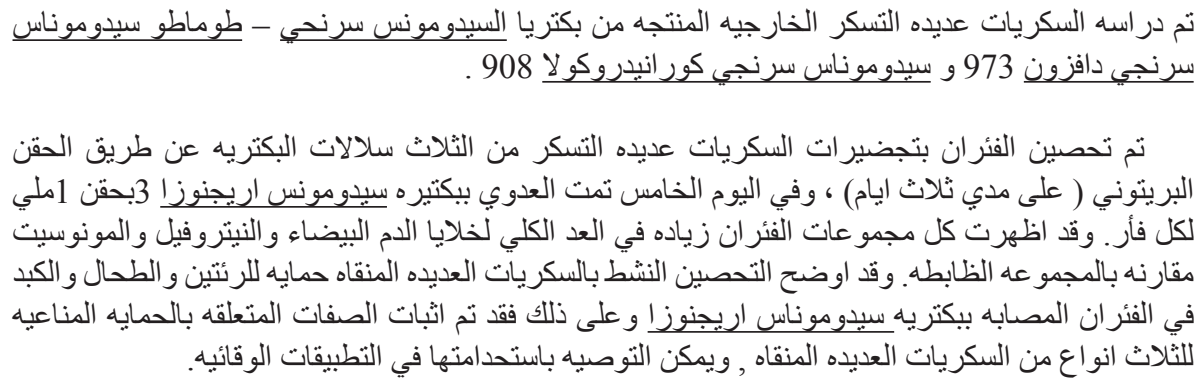

